\title{
Studies on engineering properties of raw and roasted pulses
}

\author{
Upali Sahu*, Kamlesh Prasad, Prithyiraj SahoO ${ }^{1}$ and B.B. Sahu ${ }^{1}$
}

Department of Food Engineering and Technology, Sant Longowal Institute of Engineering and Technology, LONGOWAL SANGRUR (PUNJAB) INDIA

${ }^{1}$ AICRP on APA, Central Institute of Freshwater Aquaculture, BHUBANESWAR (ODISHA) INDIA (Email: binodbsahu @ gmail.com)

*Author for Correspondence

Research chronicle : Received : 31.07.2014; Accepted : 28.11.2014

\begin{abstract}
SUMMARY :
The physico-chemical properties of various raw and roasted pulses (bengal gram: JG-11, green gram: LGG460, horse gram: PHG2, yellow pea: AP3) were investigated. The physical properties (length, breadth, thickness, geometric mean diameter, aspect ratio, sphericity, surface area), gravimetric properties (bulk density, true density and porosity), frictional properties (angle of repose and static co-efficient of friction), and optical properties $\left(\mathrm{L}, \mathrm{a}^{*}, \mathrm{~b}^{*}, \Delta \mathrm{E}\right)$ were studied for some of the varieties of pulses and compared between roasted and unroasted pulses. The engineering properties were determined in compliance with ASAE Standard 5352.1 (1984). Results obtained showed a bulk density ranging from 998.46 in yellow pea (Pisum Satirum) seed to $616.86 \mathrm{~kg} / \mathrm{m}^{3}$ in horse gram (Dolichos biflorus) seed, both roasted and unroasted pulses. Bulk density of raw pulses showed a increasing trend than the roasted pulses. The relation between length, breadth, thickness, arithmetic mean, geometric mean, volume, sphericity, bulk and true density, porosity, surface and specific surface follow a strict pattern which enables the reliable correlation of geometrical dimensions to the unit mass. Angle of repose of studied pulses varied from 72.42 to 76.84 degrees. Angle of repose of roasted pulses recorded higher values than the raw grains. The correlations could be used for sorting, conveying and hopping. The engineering and mechanical properties of various pulses vary considerably. The correlation found in this study is useful for handling, sorting and conveying purpose.
\end{abstract}

KEY WORDS : Engineering properties, Physical properties, Pulses, India

How to cite this paper : Sahu, Upali, Prasad, Kamlesh, Sahoo, Prithviraj and Sahu, B.B. (2014). Studies on engineering properties of raw and roasted pulses. Internat. J. Proc. \& Post Harvest Technol., 5 (2) : 184-188. 